\title{
Influence of mechanical activation of polytetrafluoroethylene matrix of tribotechnical composites on its structural and phase transformations and properties
}

\author{
O.A.Budnik ${ }^{1}$, A.F.Budnik ${ }^{2}$, K.V.Berladir ${ }^{2}$, \\ P.V.Rudenko ${ }^{2}$, V.A.Sviderskiy ${ }^{3}$ \\ ${ }^{1}$ Belgorod State Technological University of V.Shukhov, \\ 46 Kostyukova Str., 308012 Belgorod, Russia \\ ${ }^{2}$ Sumy State University, 2 Rimsky-Korsakov Str., 40007 Sumy, Ukraine \\ ${ }^{3}$ National Technical University of Ukraine "Kyiv Polytechnic Institute", \\ 37 Pobedy Ave., 03056 Kyiv, Ukraine
}

Received December 24, 2014

Structure of the powdered polytetrafluoroethylene (PTFE) before and after intensive mechanical activation (mechanical alloying) is investigated by the set of physical research methods (electronic microscopy, differential thermal analysis and thermography, diffraction, IR spectroscopy). It is shown that mechanical activation of PTFE leads to formation of granules with micron-sized, filamentous strands of nanometer thickness and other formations which are not typical for industrial PTFE samples. Features of the structure of activated PTFE macromolecules, leading to increased wear resistance to are observed. Obtained results and examples of implementation of the developed tribotechnical composites are analyzed.

Keywords: polytetrafluoroethylene, mechanical activation, structure, properties, tribotechnical composites.

Совокупностью физических методов исследований (электронной микроскопии, дифференциального термического анализа и термографии, дифрактометрии, ИК-спектроскопии) изучено строение порошкообразного политетрафторэтилена (ПТФЭ) до и после интенсивной механической активации (механического легирования). Показано, что механическая активация ПТФЭ приводит к образованию гранул с микронными размерами, нитевидных прядей наноразмерной толщины и других образований, не свойственных промышленным образцам ПТФЭ. Наблюдаются особенности строения макромолекул активированного ПТФЭ, ведущих к увеличению сопротивления изнашиванию. Проанализированы полученные результаты, приведены примеры внедрения разработанных триботехнических композитов.

Вплив механічної активації політетрафторетиленової матриці тріботехнічних композитів на її структурно-фазові перетворення і властивості. О.А.Будник, А.Ф.Будник, Х.В.Берладір П.В.Руденко, В.А.Свідерський.

Сукупністю фізичних методів досліджень (електронної мікроскопії, диференціального термічного аналізу і термографії, дифрактометрії, ІЧ-спектроскопії) вивчено будову порошкоподібного політетрафторетилену (ПТФЕ) до і після інтенсивної механічної активації (механічного легування). Показано, що механічна активація ПТФЕ призводить до утворення гранул з мікронними розмірами, ниткоподібних пасом нанорозмірної товщини та інших утворень, не властивих промисловим зразкам ПТФЕ. Спостерігаються особливості будови макромолекул активованого ПТФЕ, що ведуть до збільшення опору зношування. Проаналізовано отримані результати, наведено приклади впровадження розроблених триботехнічних композитів. 


\section{Introduction}

Use of polymers as structural materials for tribotechnical application is due to many factors, including possibility to form composites with desired properties [1].

Review of the literature, patent and commercial sources [1-4] reveals a low potential of traditional technological approaches in obtaining the polymeric composite materials (PCM) based on polytetrafluoroethylene (PTFE). However, various advanced technological methods may be performed that allow obtaining the composite materials and products from them with the properties required by customers. In particular, it is synthesis of polymeric matrices of different composition and structure [3,4]; formation of mixtures by joining the polymers and oligomers with different levels of interaction [3]; modification of the matrices of various origins by means of directed restructuring and structural interaction by energy impact $[5,6]$; the matrix modifying with the help of activating additives of various sizes, shapes and properties [7, 8]; creation of nanophase matrices with significantly different characteristics [9].

The technology of energy impact on the structure and properties by means of mechanical activation (mechanical effect) looks the most acceptable in the case of the PCM with PTFE matrix [5], and it is called "mechanical alloying".

\section{Experimental}

Activation of the PTFE powder was performed on MRP-1M mill with various rotation speed of working members in the interval of $n=\left(5^{-9}\right) \cdot 10^{3} \mathrm{~min}^{-1}$ and during experimentally determined time interval of $\tau=(3-8) \mathrm{min}$.

The activated powder was obtained by dry milling in the MRP-1M high speed blade mixer.

Test samples were obtained by the cold molding technology (molding pressure $\left.P_{\text {mold }}=(50.0-70.0) \mathrm{MPa}\right)$, followed by free sintering of tablet blanks in air at $365 \pm 5^{\circ} \mathrm{C}$ at speed of heating - cooling of $40^{\circ} \mathrm{C} / \mathrm{h}$.

Tests of strength and relative elongation at break were performed on the ring samples of $50 \times 40$ diameters and $10 \mathrm{~mm}$ height using rigid half-discs at $\mathrm{R}-1$ disruptive installation at the motion speed of sliding member of $0.25 \mathrm{~cm} / \mathrm{min}$. The degree of crystallinity and crystal lattice parameters were determined using X-ray diffraction method (DRON-4-07 diffractometer) using filtered $\mathrm{CuK}_{\alpha}$ radiation (wavelength was $0.154 \mathrm{~nm}$ ), the Bragg-Brentano focusing of $\theta-2 \theta$ ( $2 \theta$ is the Bragg angle). The values of current and voltage on X-ray tube were $20 \mathrm{~mA}$ and $40 \mathrm{kV}$. Surveying of the samples was carried out in incremental registration mode (exposure is $3 \mathrm{~s}$ ), range of angles $2 \theta$ was from $16^{\circ}$ to $20^{\circ}$.

Study of the wear rate was carried out on SMT-1 friction machine according to "partial insertion-shaft" scheme. The magnitude of wear of the samples was determined gravimetrically by analytical balance within the accuracy of $10^{-5}$ grams and transferred to the intensity of wear by the known methodologies [10].

Investigation of supramolecular structure of activated PTFE powder was carried out using TESCAN MIRA 3 LMU scanning electron microscope of high resolution.

Studies of composite structures before and after friction were performed with a scanning electron microscope of high resolution TESCAN MIRA 3 LMU and BMV type optical microscope.

IR spectra of the PTFE surfaces and wear products were registered by FT-IR Nicolet 5700 spectrometer in reflection mode. The wear products had been previously tableted at the room temperature at pressure of $50 \mathrm{MPa}$. Absorption band of $\mathrm{CF}_{2}$ groups of PTFE was used as comparison band at $1206 \mathrm{~cm}^{-1}$. The relative error of optical density definition in a series of three measurements was $\sim 20 \%$.

Thermographic studies of the activated PTFE were performed by Q-1500 derivatograph at temperatures ranging from the room temperature to that which is above the melting point of the crystallites by $60-$ $70 \mathrm{~K}$ (approximately up to $700 \mathrm{~K}$ ), in the linear heating mode at air with the speed of $5-10 \mathrm{~K} / \mathrm{min}$ or cooling of the samples together with the furnace at the speed of approximately $5 \mathrm{~K} / \mathrm{min}$.

Processing of the experimental data was performed by the methods of mathematical design of experiments and mathematical statistics [11].

\section{Results and discussion}

One of the most effective and low-cost ways of produce polymer with the new properties is the method of mechanical activation (mechanical alloying) [4, 12-15].

Derivatographic study has shown that weight loss of PTFE occurs in the temperature range of $500-580^{\circ} \mathrm{C}$. Thermal behavior of the activated PTFE is different: interval 

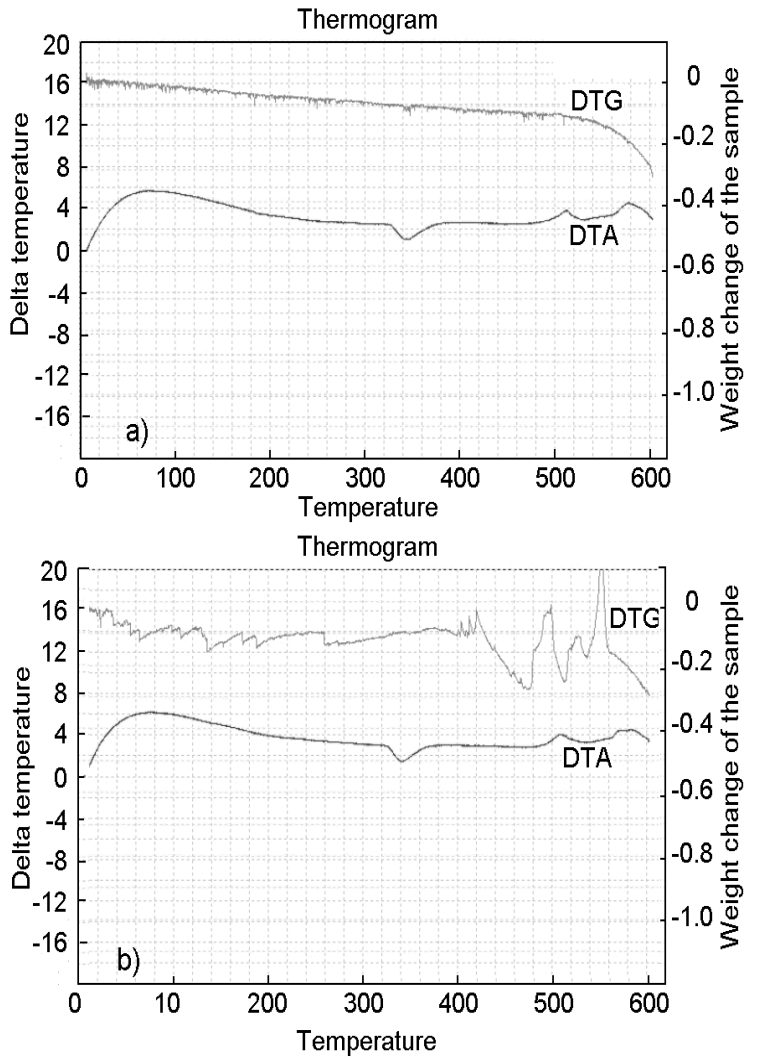

Fig. 1. Thermograms of PTFE samples (a) and its activated form (b) in activation mode $n=9 \cdot 10^{3} \min ^{-1}$ and $\tau=5 \mathrm{~min}$. of polymer decomposition is $580-600^{\circ} \mathrm{C}$ (regions appear of slow $(200-420)^{\circ} \mathrm{C}$ and rapid $(420-520)^{\circ} \mathrm{C}$ thermal decomposition (Fig. 1)).

The results of thermographic analysis of the samples of materials show that PTFE mechanical activation increases macromolecule rigidity and leads to an increase in the thermal resistance of the modified polymer at $20-80^{\circ} \mathrm{C}$. This is due to the presence of phases with different thermal resistance due to their different molecular weight.

In the structure of the PTFE samples after mechanical activation, lentil-like formations are observed in the form of granules with micron dimensions in area and thickness (Fig. 2, b), threadlike strands of fibers with length of 10 to $50 \mu \mathrm{m}$ and diameter from 10 to $100 \mathrm{~nm}$ (Fig. 2, c) and other formations ("cobweb", "frost flowers", "lace" and "branch" structures, etc.) (Fig. 2, d-f), which are absent in the nonactivated PTFE structure (Fig. 2, a).

Difference between particle morphology of fractions is due to the fact that the products obtained at different thermobaric effects have different ratio of the molecular components, and each of them is intended to construction of certain morphological formations.

The study results given in Figures show that division into nano- and microscale ob-

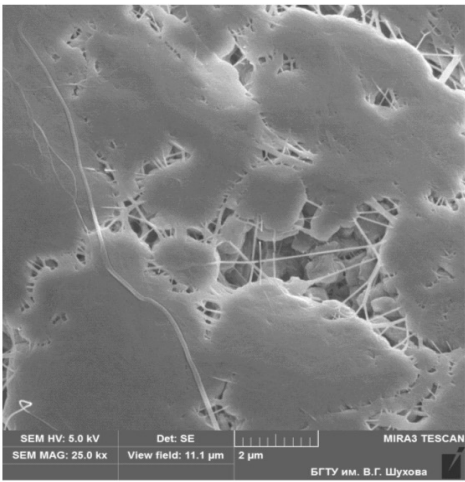

a)

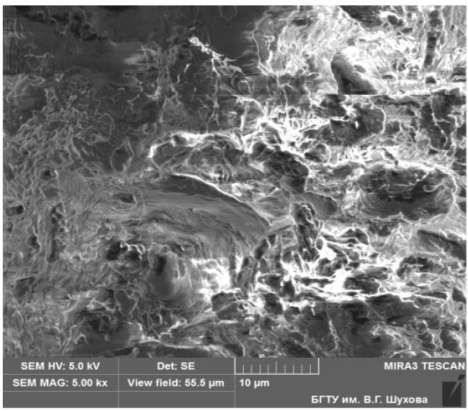

d)

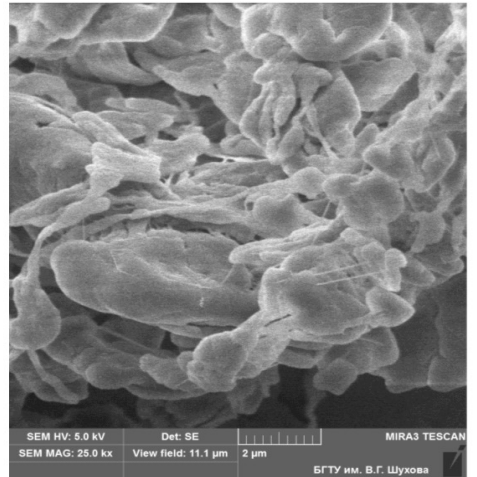

b)

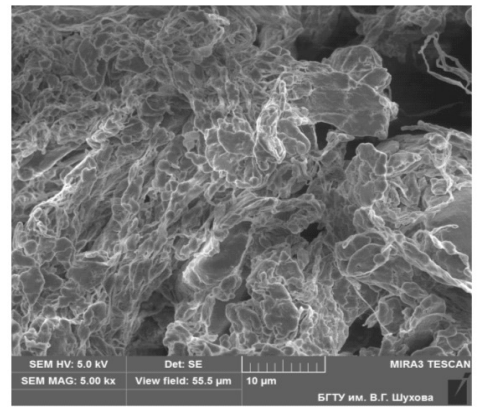

e)

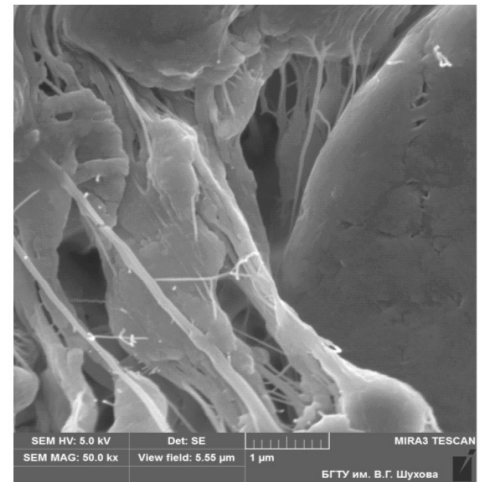

c)

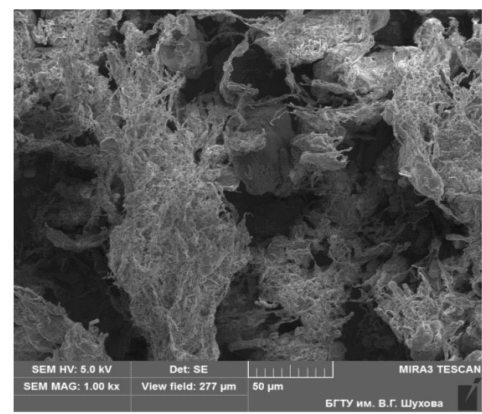

f)

Fig. 2. Structure of PTFE before (a) and after $(b-f)$ mechanical activation. 


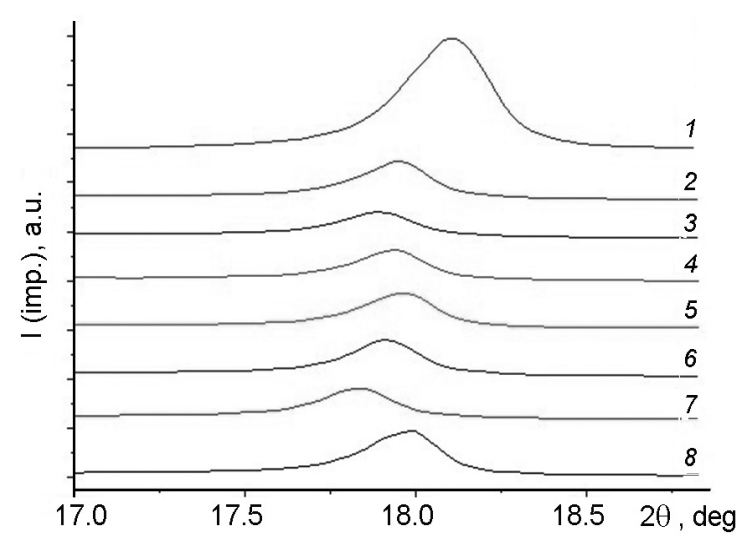

Fig. 3. Diffraction curves of PTFE (1) and its modifications (2-8) after mechanical activation. Marking of the samples is in accordance with Table 1.

jects in the case of fluoropolymers is conditional. Basically, the nanoobjects are parts that form the microobjects.

The difference is also found in the X-ray diffractograms of the non-activated and mechanical activated PTFE (Fig. 3).

Fig. 3 (curve 1) shows that the PTFE amorphous ring is located at $2 \theta=18.10$ degrees. Intensive mechanical activation shifts it to the region of the lower Wulff-Bragg angles $(2 \theta=17.82-17.98$ deg. $)$, simultaneously reducing the intensity (Fig. 3, curves 2-8). Significant decrease in the intensity of diffracted radiation (3.1 times) is observed in the samples (sample 7) manufactured after PTFE activation at $n=9 \cdot 10^{3} \mathrm{~min}^{-1}$ during $\tau=5 \mathrm{~min}$. At that, both the cell parameters and crystallite sizes in the plane (100) undergo changes (Table 1), which provides the optimal-reacting structure of PTFE in obtaining of the composite.

Physical and mechanical properties of PTFE are maximum at that and in terms of breaking strength $\left(\sigma_{b}\right)$ are 2.6 times more than in the case of the non-activated PTFE, in terms of relative elongation ( $\delta$ ) 4.3 times, and the wear intensity of the material is $54 \%$ less.

Therefore, it is logical to conclude that the intense energy impact in the form of mechanical activation has significant influence on formation of the special supramolecular structure of PTFE, which from the standpoint of mechanics of the polymers has positive effect on physical and mechanical properties of the polymer.

The study of the molecular and supramolecular structure of polytetrafluoro-
Table 1. X-ray structure analysis

\begin{tabular}{|c|c|c|c|}
\hline $\begin{array}{c}\text { No. of } \\
\text { sample }\end{array}$ & $\begin{array}{c}\text { Size of } \\
\text { crystallites } \\
\text { in the plane } \\
(100), \mathrm{nm}\end{array}$ & $\begin{array}{c}\text { Parameters } \\
\text { of unit cell } \\
a=b, \mathrm{~nm}\end{array}$ & $\begin{array}{c}\text { Parameter } \\
\text { of cell } c, \mathrm{~nm}\end{array}$ \\
\hline 1 & 29 & 0.566 & 0.972 \\
2 & 28 & 0.570 & 0.949 \\
3 & 26 & 0.572 & 0.949 \\
4 & 29 & 0.570 & 0.921 \\
5 & 29 & 0.570 & 0.921 \\
6 & 29 & 0.571 & 0.959 \\
7 & 27 & 0.574 & 0.965 \\
8 & 31 & 0.570 & 0.965 \\
\hline
\end{tabular}

ethylene in this paper is performed by IR spectroscopy method.

In carrying out theoretical analysis of the vibrational spectra of polytetrafluoroethylene, structural model is usually accepted in which the unit cell contains one molecular chain $\mathrm{C}_{n} \mathrm{~F}_{2 n+2}$ [16].

Fig. 4 shows a typical IR spectrum of polytetrafluoroethylene [16].

As is seen from Fig. 4, the most intense bands refer to the valence vibrations of $\mathrm{CF}_{2}$ groups (1211 and $1154 \mathrm{~cm}^{-1}$ ) and vibration $v$ (CC), which manifests itself in the form of a bend at $\sim 1233 \mathrm{~cm}^{-1}$. The region below $650 \mathrm{~cm}^{-1}$ contains deformation and out-ofplane vibrations of $\mathrm{CF}_{2}$ groups: wagging vibrations $\gamma_{\omega}\left(\mathrm{CF}_{2}\right)$ appear at $639 \mathrm{~cm}^{-1}$, bands 555 and $516 \mathrm{~cm}^{-1}$ characterize the deformation and pendular oscillations of $\mathrm{CF}_{2}$ groups, respectively [16, 17].

The studies have shown that optical density of band at $780 \mathrm{~cm}^{-1}$ observed in the IR spectra of PTFE increases linearly with decreasing the degree of crystallinity of the sample. This band is used to determine the degree of ordering in polytetrafluoroethylene structure [18]. We refer it and several other bands observed in 700-800 $\mathrm{cm}^{-1}$ region, to the vibrations of molecular chains in the amorphous phase. The bands at 640,625 and $516 \mathrm{~cm}^{-1}$ are considered as ordering bands [19]. They are also considered as the crystallinity bands. The half-width of the band at $516 \mathrm{~cm}^{-1}$ changes abruptly, which corresponds to phase transition in the crystall ine polytetrafluoroethylene.

When modifying polytetrafluoroethylene by mechanical activation treatment, the transition of polymer into dispersed, ultradispersed and another state ("threads", 


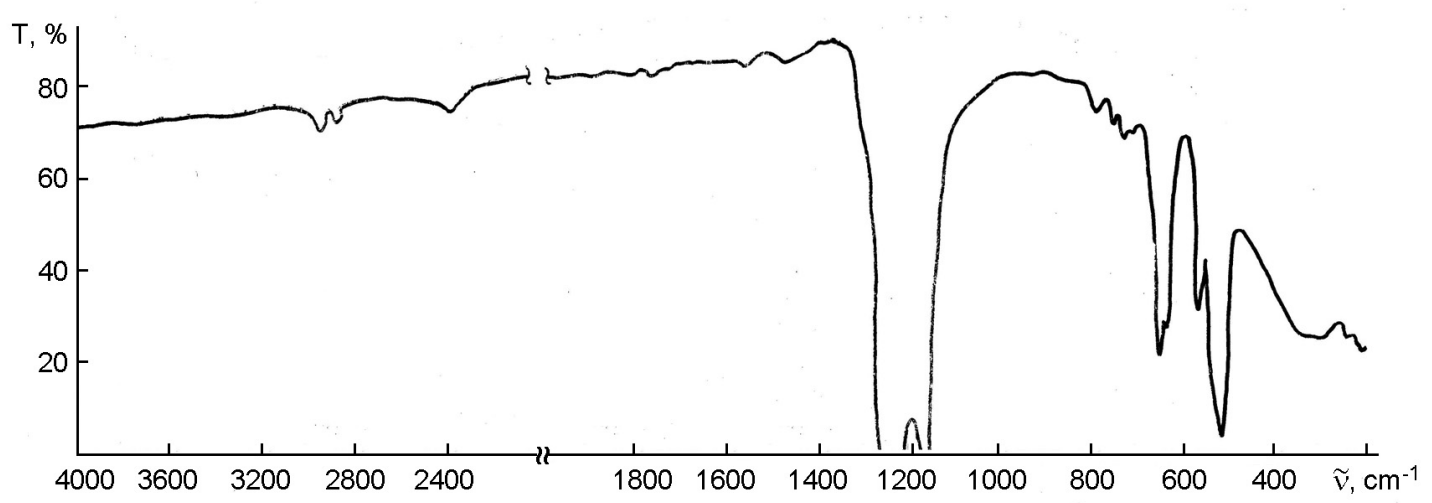

Fig. 4. IR absorption spectrum of polytetrafluoroethylene.

"cobweb", "lace", "branch", etc.) occur (Fig. 2).

Usually, in the IR spectra of these formations, bands are preserved that characterize the valence vibrations of $\mathrm{C}-\mathrm{F}$ and $\mathrm{C}-\mathrm{C}$, deformation vibrations of $\mathrm{CCC}$ and $\mathrm{CF}_{2}$ groups, out-of-planevibrations of $\mathrm{CF}_{2}$-groups, individual fragments and whole chain [1618], even with intense energy impact. This suggests the idea that external influence does not lead to complete destruction of polytetrafluoroethylene molecular chain. However, there is an assumption that certain changes are taking place at the molecular level, that lead to changes in the polymer properties.

Analysis of the research conducted indicates the changes in morphology and supramolecular structure of polytetrafluoroethylene after treatment, even while maintaining the chemical structure of the polymer. The IR spectra are sensitive to such changes and provide information about the structure of the modified polymer forms.

Fig. 5 shows the absorption spectrum of PTFE after the energy impact in mode $n=$ $9 \cdot 10^{3} \min ^{-1}$ and $\tau=5 \mathrm{~min}$.

As you would expect, in the case of PTFE mechanical activation the change in shape and intensity ratio of most bands is observed.

It is known that the amorphous state of the polymer [4] is often caused not only by the deficiency of the macromolecule, but also reflects a decrease in the degree of crystallinity, which is caused by reasons of the physical nature, such as existence of the potential barriers to internal rotation and the potential minima for specific conformations. Ordered regions of the polymer quantitatively characterized by the crystallinity

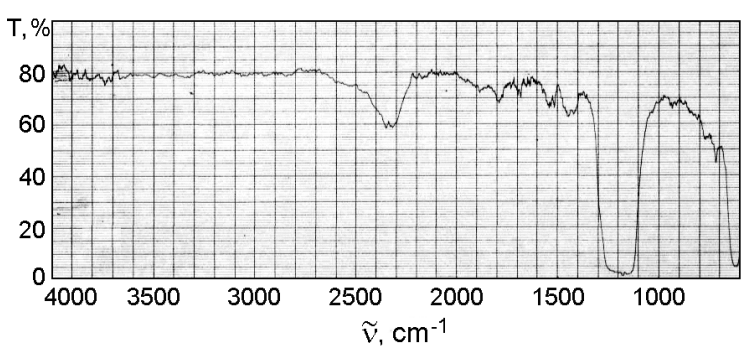

Fig. 5. IR spectra of PTFE after mechanical activation in mode $n=9 \cdot 10^{3} \mathrm{~min}^{-1}$ and $\tau=$ 5 min.

degree. The IR spectroscopy is used to characterize the polymer bands whose intensity changes with the crystallinity of the polymer [18].

When comparing the IR spectra of the non-activated and activated PTFE, some differences are observed. They consist in increase of intensity of the bands in 700-800, 620,575 and $490 \mathrm{~cm}^{-1}$ region. In the IR spectrum of PTFE, the most intense bands are 1211 and $1154 \mathrm{~cm}^{-1}$ corresponding to the valence vibrations of $\mathrm{CF}_{2}$ groups. In the activated PTFE, shift of these bands and increase in their intensity $\left(1175 \mathrm{~cm}^{-1}\right)$ is observed. Bending of the vibrations $v$ (CC) at $1233 \mathrm{~cm}^{-1}$ in PTFE is shifted into the high-frequency region of the spectrum in the activated PTFE $\left(1350 \mathrm{~cm}^{-1}\right)$. In 8001100 and $1350-2230 \mathrm{~cm}^{-1}$ regions, a number of additional bands, which are absent in the non-activated PTFE spectrum, is observed, which can be attributed to vibrations of finite groups and groups of the offshoot of the structural fractions. The band at $2390 \mathrm{~cm}^{-1}$ in the non-activated PTFE is shifted to the low-frequency region of the activated PTFE spectrum $\left(2330 \mathrm{~cm}^{-1}\right)$, significantly expanding and intensifying. 
Table 2. Effect of mechanical activation of PTFE on physical and mechanical and tribotechnical properties

\begin{tabular}{|c|c|c|c|c|c||}
\hline $\begin{array}{c}\text { No. of } \\
\text { sample }\end{array}$ & Technology of obtaining & $\begin{array}{c}\text { Density } \rho, \\
\mathrm{g} / \mathrm{cm}^{3}\end{array}$ & $\begin{array}{c}\text { Breaking } \\
\text { strength } \sigma_{v}, \\
\mathrm{MPa}\end{array}$ & $\begin{array}{c}\text { Relative } \\
\text { elongation } \delta, \%\end{array}$ & $\begin{array}{c}\text { Wear intensity } \\
I \cdot 10^{-6}, \\
\mathrm{~mm} / \mathrm{N} \cdot \mathrm{m}\end{array}$ \\
\hline 1 & non-activated & 2.269 & 9.5 & 96 & 1133 \\
2 & $\tau=5 \mathrm{~min}, n=5 \cdot 10^{3} \mathrm{~min}^{-1}$ & 2.211 & 21.6 & 416 & 930 \\
3 & $\tau=8 \mathrm{~min}, n=5 \cdot 10^{3} \mathrm{~min}^{-1}$ & 2.175 & 17.3 & 280 & 800 \\
4 & $\tau=5 \mathrm{~min}, n=7 \cdot 10^{3} \mathrm{~min}^{-1}$ & 2.205 & 23.5 & 423 & 820 \\
5 & $\tau=8 \mathrm{~min}, n=7 \cdot 10^{3} \mathrm{~min}^{-1}$ & 2.211 & 18.2 & 358 & 717 \\
6 & $\tau=3 \mathrm{~min}, n=9 \cdot 10^{3} \mathrm{~min}^{-1}$ & 2.203 & 19.6 & 290 & 890 \\
7 & $\tau=5 \mathrm{~min}, n=9 \cdot 10^{3} \mathrm{~min}^{-1}$ & 2.214 & 24.8 & 415 & 610 \\
8 & $\tau=8 \mathrm{~min}, n=9 \cdot 10^{3} \mathrm{~min}^{-1}$ & 2.213 & 18.0 & 340 & 720 \\
\hline
\end{tabular}

The expanding of the XRD line - is the result of the mosaic structure of matter, or disordering within the lamella [20]. It should be also noted that the vibrations in the activated PTFE spectrum in 2900$4000 \mathrm{~cm}^{-1}$ region in the non-activated polymer generally are not detected.

In our opinion, expanding of the band in the IR spectrum at maximum absorption is due to formation of many powdered crystallites in the polymer structure, which do not affect the degree of crystallinity in dominating way, but form the structure that most effectively resists breaking of bonds, and therefore wear. This contributes to significant increase in wear resistance of the materials friction unit.

Thus, in the case of the PTFE modification as a result of mechanical activation, transition of the polymer into dispersed, nanodispersed and other actively structural states occurs (alloying of the polymer).

The studies determined that the difference between the structural and morphological structure of the activated and non-activated PTFE leads to the differences in the properties (Table 2).

During the researches it was found that the activated PTFE has the optimal ratios of physical-mechanical and tribotechnical properties in mode of $n=9 \cdot 10^{3} \min ^{-1}$ and $\tau=5 \mathrm{~min}$ (sample 7): breaking strength $\sigma_{b}=24.8 \mathrm{MPa}$, relative elongation $\delta=415 \%$, wear intensity $\mathrm{I}=610 \cdot 10^{-6} \mathrm{~mm}^{3} / \mathrm{N} \cdot \mathrm{m}$. The non-activated PTFE has $\sigma_{b}=9.5 \mathrm{MPa}, \delta=96 \%, I=1133 \cdot 10^{-6} \mathrm{~mm}^{3} / \mathrm{N} \cdot \mathrm{m}$.

The influence of external forces in the mechanical activation on unfilled PTFE increases the parameters of its deformation and strength characteristics (breaking strength in 2.6 times, relative elongation in
4.3 times) while maintaining the high tribotechnical performance. This is obviously related to formation of the new reaction centers and increase in the surface energy of the individual fragments of macromolecules as a result of elastic and plastic deformations at the mechanical influence.

Thus, improving of the wear resistance of the PTFE in mechanical activation associated with the reduced degree of crystallinity and increase in the average interlayer distance in the frictional interaction and structural adaptability of modified PTFE in friction and manifestation of synergistic effects of self organization tribotechnical structures with increased durability.

The mechanically activated PTFE more actively adheres to the surface of CF (Fig. 6, a-c) than the non-activated (Fig. 6, d) in obtaining of PCM. This results in modification of the surface layer CF by the activated PTFE, PTFE fragments are distributed on the surface CF with higher homogeneity that enhances their activity in interactions with the PTFE matrix during the formation of the composite. The homogeneous composite structure is formed with fewer voids and with formation of more uniform distribution of the fragments of the filler in the matrix polymer. CF particles are contacted with the activated particles of PTFE and formed primary adhesive bonds, which reduce the defectiveness of the mixture and probability of occurrence of the defects during the forming of composite.

Composites filled with CF, created on the basis of such an activated matrix, have significantly higher tribotechnical performance (Table 3) than the non-activated matrix. 


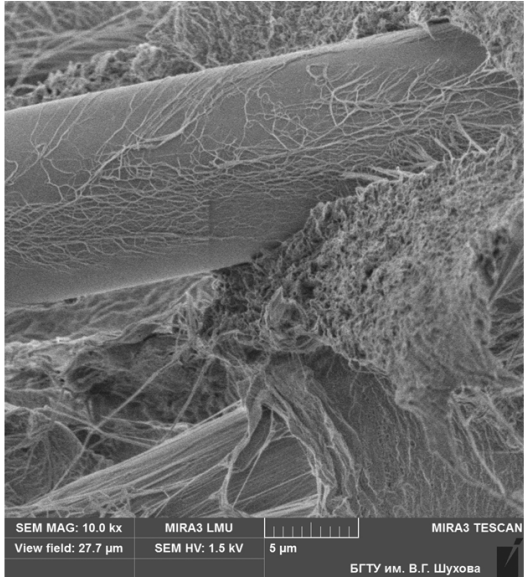

a)

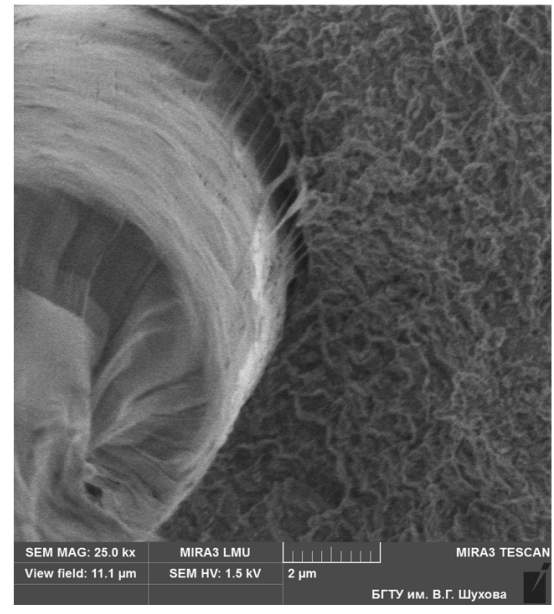

c)

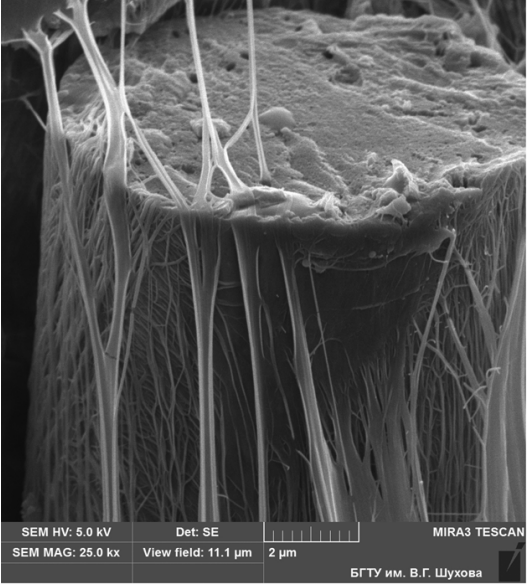

b)

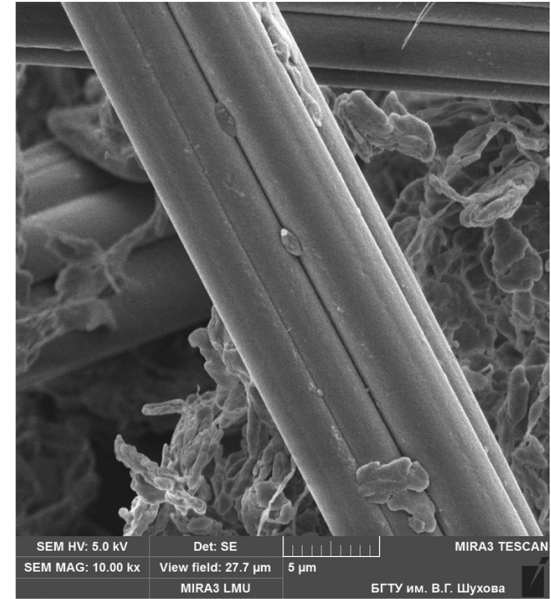

d)

Fig. 6. Microphotographs of PTFE composite structures with CF with activated (a-c) and non-activated (d) matrix.

Microphotographs of the friction surface of the composites (Fig. 7) show that by increasing the adhesive bond "activated matrix PTFE-filler" wear process is less active than the non-activated composite matrix. The microphotographs clearly show that in the case of wear of the PTFE composite non-activated (Fig. 7, a) marks of wear are deeper, observed the furrows of temper softening material, etc., which is not observed in the wear composite with activated PTFE (Fig. 7, b), and contributes to increasing durability to $50 \%$.

The use of this composite as friction units compressors 4GM $2.5 \quad 2 / 3 \quad 250,2 \mathrm{RV}$ $3 / 220$, SA 1174 , SA 7171 (gland seals and piston rings) contributed to the overall increase its efficiency by $2.3-3.0$ times.

\section{Conclusions}

Mechanical activation of PTFE matrix leads to the change in its supramolecular structure and increase of its reactivity.

Such change leads to formation of the polymeric structures that are not in the non-activated polymer and which greatly increase the wear resistance of the material.

The activated PTFE has the best parameters in activation mode $n=9 \cdot 10^{3} \mathrm{~min}^{-1}$ and $\tau=5$ min: breaking strength $\sigma_{b}=$ $24.8 \mathrm{MPa}$, relative elongation $\delta=415 \%$, wear intensity $I=610 \cdot 10^{-6} \mathrm{~mm}^{3} / \mathrm{N} \cdot \mathrm{m}$. The nonactivated PTFE has $\sigma_{b}=9.5 \mathrm{MPa}, \delta=96 \%$, $I=1133 \cdot 10^{-6} \mathrm{~mm}^{3} / \mathrm{N} \cdot \mathrm{m}$.

PCM based on the activated PTFE have physical and mechanical characteristics of 3-5 times higher than the non-activated, durability in 1.5-2.0 times higher. 
O.A.Budnik et al. / Influence of mechanical activation...

Table 3. Properties of PTFE composites depending on use of activated and non-activated matrix

\begin{tabular}{|c|c|c|c|c|c|c|c|c|}
\hline \multirow[t]{3}{*}{ Composite } & \multicolumn{8}{|c|}{ Properties } \\
\hline & \multicolumn{2}{|c|}{$\begin{array}{l}\text { Density } \\
\rho, \mathrm{g} / \mathrm{cm}^{3}\end{array}$} & \multicolumn{2}{|c|}{$\begin{array}{l}\text { Breaking strength } \sigma_{b}, \\
\mathrm{MPa}\end{array}$} & \multicolumn{2}{|c|}{$\begin{array}{c}\text { Relative elongation } \delta \text {, } \\
\%\end{array}$} & \multicolumn{2}{|c|}{$\begin{array}{c}\text { Wear intensity } I \cdot 10^{-6}, \\
\mathrm{~mm}^{3} / \mathrm{N} \cdot \mathrm{m}\end{array}$} \\
\hline & $\begin{array}{c}\text { non- } \\
\text { activated }\end{array}$ & activated & $\begin{array}{c}\text { non- } \\
\text { activated }\end{array}$ & activated & $\begin{array}{c}\text { non- } \\
\text { activated }\end{array}$ & activated & $\begin{array}{c}\text { non- } \\
\text { activated }\end{array}$ & activated \\
\hline $\mathrm{F}_{4} \mathrm{CF}_{10}$ & 2.01 & 2.02 & 17.5 & 17.9 & 90 & 98 & $25-60$ & $21-51$ \\
\hline $\mathrm{F}_{4} \mathrm{CF}_{15}$ & 1.98 & 1.99 & 18.3 & 19.1 & 105 & 115 & $20-50$ & $17-42$ \\
\hline $\mathrm{F}_{4} \mathrm{CF}_{20}$ & 1.96 & 1.98 & 20.4 & 22.1 & 120 & 145 & $19-45$ & $16-38$ \\
\hline $\mathrm{F}_{4} \mathrm{CF}_{25}$ & 1.95 & 1.96 & 16.9 & 18.4 & 115 & 125 & $18-40$ & $15-34$ \\
\hline
\end{tabular}

Note. The numbers after carbon fiber in the composite mark indicate its weight content $(10,15,20$, 25 wt. $\%$, respectively).

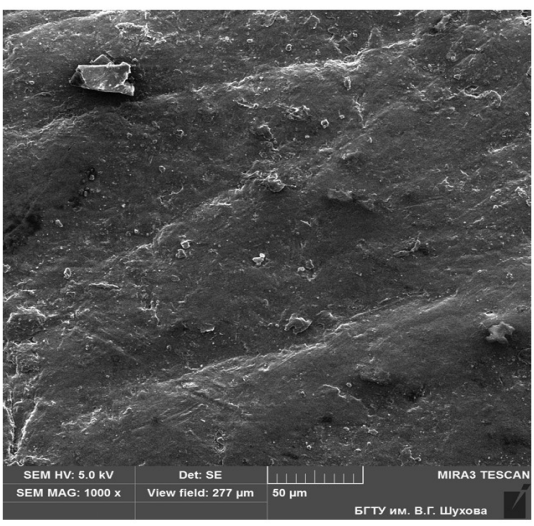

a)

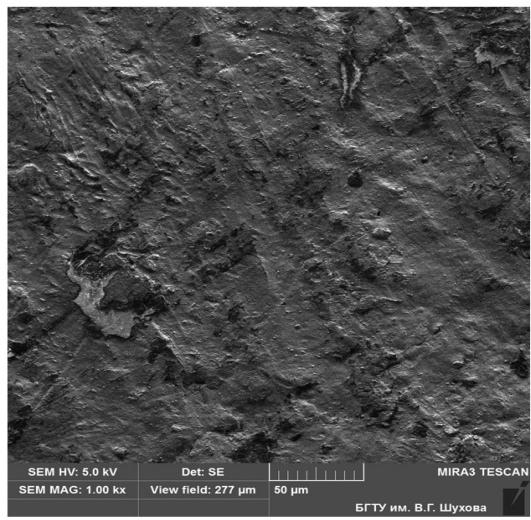

b)

Fig. 7. Microphotographs of the friction surface of PTFE composites with non-activated (a) and activated (b) matrix.

\section{References}

1. Y.K.Mashkov, Z.N.Shepherd, V.I.Surikov, L.F.Kalistratova, Composite Materials Based on Polytetrafluoroethylene. Structural Modification, Mashinostroyeniye, Moscow (2005) [in Russian].

2. S.V.Avdeychik, Tribochemical Technology of Functional Composite Materials, GGAU, Grodno (2008) [in Russian].

3. J.Manson, L.Sperling, Polymer Blends and Composites, Khimiya, Moscow (1979) [in Russian].

4. Y.S.Lipatov, Physical Chemistry of Polymers, Khimiya, Moscow (1977) [in Russian].

5. P.N.Petrova, O.V.Gogoleva, Oil and Gas Business, No.2, 298 (2011).

6. O.A.Budnik, V.A.Sviderskiy, K.V.Berladir et al.,Vestnik BGTU im.V.G.Shukhova", No.4, 10 (2014).

7. V.M.Buznik, V.M.Fomin, A.P.Alkhimov, Metallpolimer Nanocomposites (Production, Properties, Application), SO RAN, Novosibirsk (2005) [in Russian].

8. A.A.Okhlopkova, A.V.Vinogradov, L.S.Pinchuk, Plastic, Filled with Ultrafine Inorganic Compounds, IMMS NANB, Gomel (1999) [in Russian].
9. S.N.Chvalun, Priroda, No. 1, 1 (2010).

10. I.V.Kragelskiy, M.N.Dobychin, V.S.Kambalov, The Basis of Calculation for Friction and Wear, Mashinostroyeniye, Moscow (1977) [in Russian].

11. Y.P.Adler, Introduction to Experimental Design, Metallurgiya, Moscow (1965) [in Russian].

12. N.K.Baramboym, Mechanochemistry of Macromolecular Compounds, Khimiya, Moscow (1978) [in Russian].

13. A.F.Budnik, K.V.Berladir, V.A.Sviderskiy et al., East.-Europ. J. Enter. Techn., No.2/11 (68), 9 (2014).

14. O.A.Budnik, K.V.Berladir, A.F.Budnik, P.V.Rudenko, Probl. Tertya ta znosh., 4 (65), 130 (2014).

15. V.V.Boldyrev, Sorosovs. Obrazovat. Zh., 12, 48 (1997).

16. I.Dehant, R.Dants, V.Kimmer, R.Shmolke, Infrared spectroscopy of polymers, Khimiya, Moscow (1976) [in Russian].

17. V.M.Buznik, L.N.Ignateva, Rus. Khim. Zh., 3, 139 (2008).

18. L.N.Ignateva, A.K.Tsvetnikov, A.N.Livshits et al., J. Str. Chem., 1, 69 (2002).

19. T.A. Blanchet, Y.1. Peng, Lubrication Eng., 6, 489 (1996). 